\title{
C2F2C Strategy Development: The Sichuan Fanqing Furniture Industry Company Case Study
}

\author{
Zhong Liang1, Yin Jin1, Maria Santos² \\ ${ }^{1}$ University of Electronic Science and Technology of China, Chengdu, China \\ ${ }^{2}$ ISCTE-University Institute of Lisbon, IBS, Lisboa, Portugal \\ Email: 1412575923@qq.com,yinj@uestc.edu.cn, maria.santos@iscte-iul.pt
}

How to cite this paper: Liang, Z., Jin, Y. and Santos, M. (2019) C2F2C Strategy Development: The Sichuan Fanqing Furniture Industry Company Case Study. Open Journal of Social Sciences, 7, 61-71. https://doi.org/10.4236/jss.2019.710006

Received: July 1, 2019

Accepted: October 14, 2019

Published: October 17, 2019

\begin{abstract}
In a context of fragmentated competition and consumers' demand, it is difficult to take advantage of the low cost and high efficiency of mass customization, while and also meeting the customers' individualized needs. Internet led business increases the difficulty of balancing the offer of large production and customization, because companies face a high cost (C2F), while the customer's satisfaction is low (F2C). Finding a solution to this trade-off is not only a major challenge in the process of company model transformation, but also an important topic that has not yet been studied in depth. This research applied the case analysis method to study the evolution of hotel furniture company innovation ecosystem and to suggest the development of value co-creation model. Meanwhile, the C2F2C development strategy of creating value between hotel furniture manufacturers and customers is constructed, which realizes the win-win value creation between companies and customers, and explores the effective ways to improve the technological innovation ability and international competitiveness of hotel furniture manufacturers in China.
\end{abstract}

\section{Keywords}

Innovation Ecosystem, Value Co-Creation, Hotel Furniture Company, C2F2C Strategy-Customer to Firm, Firm to Customer Strategy

\section{Introduction}

The Internet expansion in China gradually exposed the problems of hotel furniture manufacturers, due to low production efficiency and service capacity, low concentration of the furniture industry and weak brand recognition. These companies cannot meet the new industrial requirements of 2025 made in China if they do not adapt to the internet consumption era. Consumer awareness in- 
creased the request for faster delivery at a lower cost. In order to obtain sustainable competitive advantage in the fierce market competition, the hotel furniture manufacturers need to construct a new customer value co-creation model, in which customers can meet their needs and improve satisfaction, while the companies shall reduce costs and become more efficient.

Drawing lessons from the valuable experience of the transformation and upgrading of other industries, the hotel furniture manufacturers designed a costumer-centered strategy based on a C2F (customer to factory) model. This model focuses on the introduction of custom furniture-based innovative activities to meet the consumer needs. However, in practice, the strategic management measures to fully meet the needs of consumers may reduce corporate profits. According to the data from 2018-2023 China Customized Furniture Industry Panoramic Survey and Development Strategy Research Consulting Report, the average gross profit margin of China's custom furniture industry was between $30 \%$ and $50 \%$, but the average net profit margin was only about $3 \%$ to $7 \%$. Sofia, Haolaike, European pie and other domestic custom furniture giants have a net interest rate of only more than $10 \%$. This phenomenon of high gross profit and low net profit is the pain point of furniture industry at present. This reflects the contradiction between the personalized and fragmented demand of the major hotels regarding their decoration style and the large-scale and mass production of hotel furniture production companies. This has become a key obstacle to prevent many furniture manufactures from obtaining competitive advantage.

This research explores a solution to this major challenge faced by hotel furniture manufacturers, based on the theoretical perspective of value co-creation based on Fanqing Hotel Furniture Company. The case study method is used to analyze the value co-creation model and the key influencing factors in the process of continuous evolution by analyzing the following main problems: the composition of the innovation ecosystem of hotel furniture manufacturers; the operation mode and evolution of the value co-creation between hotel companies and customers in the process of developing an innovation ecosystem; how Fanqing Furniture Company can solve the contradiction between customer personalized demand and company mass customization and improve customer satisfaction; how can the Company construct and implement the C2F2C development strategy based on value co-creation.

The literature review of relevant theories, followed by the analysis of the composition and the relationships of the innovative ecosystem of this company, allowed the proposal of a value co-creation model of hotel furniture manufacturer leading to the promotion of an innovative ecosystem based on the design and implementation of the $\mathrm{C} 2 \mathrm{~F} 2 \mathrm{C}$ strategy of Fanqing Company.

\section{Theoretical Literature Review}

\subsection{Innovation Ecosystem}

The concept of innovation ecosystem is rooted in "ecosystem". In 1935, British 
biologist Tansley (1947) first put forward the concept of "ecosystem", which included the whole complex of physical factors forming the environment. The researcher believed that "ecosystem" was the basic unit of nature, with various sizes and types [1]. In the 1970s, the concept of "ecosystem" was applied in the economic field. Scholars put forward, first the "company life cycle theory" by studying the organizational behavior of companies, and after the concepts of company ecosystem, industry ecosystem and national ecosystem. These concepts and theories further enriched the connotation of company organizational behavior management, which is not only applied on strategic management and innovation management, but also at the level of company economic management.

Since the sixties, the innovation ecosystem has passed by three stages: technological innovation, innovation system and innovation ecosystem. The term "innovation" was first proposed by Schumpeter, although without a strict and narrow definition of the term "innovation". Rostow, an American economist, put forward the take-off six-stage theory of economic development. In his book "The Diffusion of Innovation", the author pointed out the four factors that affect the diffusion of innovation: the characteristics of innovation itself, the channels of communication, the time and the social system [2].

From 1985 to 1987, Landwell and Freeman put forward the concepts of "innovation system" and "national innovation system" successively. Freeman (1987) studied the rise of Japan's economy and proposed that "national innovation system" is a network composed of market participants and government. As a result, innovation theory has entered the stage of "national innovation system" [3]. Danish scholar Lundvall (1992) believed that the "national innovation system" depends on the efficiency of knowledge utilization. The criteria for measuring the "national innovation system" are whether knowledge can be acquired, how to obtain the real positive impact in industry and how to create value [4].

In the 21 st century, the innovation ecosystem has really formed a theoretical system and been deeply studied. The report of Innovation Cluster, published by OECD in 2001, points out that "innovation" is not the progress of scientific research in the traditional sense, but the concept of innovation formed by the interaction of industry, scientific research institutions, educational institutions and service institutions. The Innovation America published in 2004 proposed that innovation is a non-linear, flexible project, a dynamic ecosystem that interacts, communicates, and cooperates among various entities within an economic society to promote innovation. In June of the same year, the report maintaining the National Innovative Ecosystem: Maintaining the Strength of American Science and Engineering Capability pointed out that the United States has a perfect and developed innovative ecosystem to gain the dominance of the world economy and long-term prosperity of the national economy. The basic mode of innovation has evolved from "industry, university and research" to "govern- 
ment, company, university and user". This new mode of innovation is called "user-oriented innovation". Simanis and Hart (2009) gave this mode another name - "embedded innovation", which takes the needs of consumers as the core, and promotes the product and service side in reverse, promotes producers to improve, produces new products and increases value [5].

In 2010, Adner pointed out that the innovation ecosystem is a collaborative mechanism in which companies play a leading role in participating, facing consumers, and solving problems through the organic combination of various inputs and innovative achievements [6]. Li (2014) believed that the innovation ecosystem is an open and complex dynamic evolution system [7]. Zhao, Liu, Sun and $\mathrm{Ma}$ (2015) believed that the innovation ecosystem is a network formed by integrating resources, sharing resources and collaborating resources to build channels and platforms between innovation subjects in order to achieve win-win situation [8].

\subsection{Value Co-Creation}

The concept of value co-creation was first proposed by Becker (1965), which is based on the theory of consumer production. That is, the needs of consumers cannot be satisfied by any products provided by manufacturers, but only by consumers' own "production" [9] [10]. The view that value co-creation is the main source of core competitiveness has been affirmed by many studies [11]. Because the concept of value co-creation mainly concentrates on the interaction between companies and customers, the characteristics of value co-creation mainly focus on customer roles, customer contributions and customer management. Customer roles are characterized by diversification: customer as a co-producer [12]; co-distributors [13]; co-promoter [11]; experience creator [14]; innovators [15]; co-ideator [16]; co-designer [17]. The research on customer contribution mainly focuses on its motivation and reasons. Vargo and Lusch (2004) put forward two kinds of resource operand resources and operational resources [18]. Paredes (2014) believed that the operational resource hierarchy begins with basic resources, moves to compound resources, and finally becomes interrelated operational resources [19]. Arnould (2008) further classified operational resources into social, economic and cultural resources, and operand resources into resources composed of material objects and physical space [20]. Further research by Rosenbaum and Massiah (2007) shows that customers can create value together with other peers and feel two kinds of support: social emotional support and instrumental support, which are due to the reciprocity and voluntary participation of customers [21]. Maglio and Spohrer (2008) put forward the resources of power, property, physical entity and social construction. Therefore, people, technology, organization and sharing of information constitute the key contribution to the process of value co-creation [22]. According to operands and operational resources, they are classified as financial, physical, legal, human capital, organizational culture, information and related 
resources. For complexity of customer management, the final conclusion can be understood as that the role of customers determines the contribution of customers in value co-creation, and the degree of contribution depends on the environment created by customers and companies together and the expected value created in the process of co-creation [23]. Other researchers have noticed that the interaction between buyers is also an important experience of corporate satisfaction and loyalty [24], which is particularly prominent in the user community of brand creation.

Aarikka-Stenroos \& Jaakkola (2012) points out that value creation in the field of production should focus on the process in which customers participate as co-producers [25]. Recent research on co-creation focuses on: customer voice and expectation [26]; cost-function model of co-production [27]; supply chain problems and value chain management 28]; cross-functional process [29] validity of marketing strategy and operational efficiency [30] and other aspects, which provide considerable insights into the specific implementation of the value co-creation process. After reviewing the literature of value co-creation, this research holds that value co-creation is a process of two choices and a final result of mutual action. In this process, companies, consumers, process suppliers and others jointly participate in the production and operation process, to achieve their own maximum interests and the common goal of the same activities, for different areas and directions of understanding, researchers from different perspectives to solve the problem, and lead to different factors affecting value creation.

\section{Evolutionary Construction and Implementation of Sichuan Fanqing Furniture Company C2F2C Strategy}

\subsection{Composition of Innovative Ecosystem of Fanqing Furniture Company}

1) Innovative ecosystem community of Fanqing Company

Sichuan Fanqing Furniture Industry Co., Ltd. (hereinafter referred to as Fanqing) is located in Chengdu City, Sichuan Province, China. Founded in 1988, it is a professional hotel furniture company deeply engaged in the furniture market of high-end hotels in China, devoted to the furniture development, design, production, engineering and installation of high-end hotels.

On the aspect of technical R \& D population, Fanqing Company has engaged in $\mathrm{R} \& \mathrm{D}$, production, marketing and after-sales, providing a one-stop solution to the overall furniture service, more flexible management process, convenient for unified services around consumers. It owns unique production technology, management technology and design capabilities. For strategic decision-making innovation, Fanqing Company is transiting from traditional company management method and family management method to modern company management method, which is embodied in: from product-oriented management to project-oriented management; from functional management to process man- 
agement; from empirical decision-making to systematic decision-making; the atmosphere of human relations management weakened. In coordinated innovation population respect, Fanqing uses a complete ERP system from order receipt to product materials, production, sorting, logistics and installation to visualize the internal data. Customers also can learn the real time progress of order through WeChat, APP and other methods. Fanqing's ERP system makes communication more effective with customers, suppliers and among departments.

2) Innovative ecological environment of Fanqing Company

The innovative ecological environment is an external factor that affects the operation of the hotel's furniture company's innovative ecosystem. The ecological factors such as innovation infrastructure, policy incentives, and market environment constitute the innovative ecological environment. All these factors are reactions to the external environment. Only by paying attention to the changes of external environment can companies warn industry crisis, seek new business opportunities and keep fresh vitality in the process of changes.

The government has gradually improved the principles and policies of the furniture manufacturing industry and played a steady and positive role in the development of the furniture market. National regulations such as "Total Savings" and "Eight Central Regulations" have had a strong impact on the hotel market. The construction and development of high-end hotels are closely related to the original market performance. With the introduction of these policies, it not only challenges the operation of high-end hotels, but also directly affects the construction speed of high-end hotels, thus slowing down the market share. Furthermore, the current domestic market in China is facing both qualitative and quantitative growth, opportunities and challenges. At the same time, current household equipment tends to be advanced, and the industrial chain has gradually improved.

\subsection{The C2F2C Value Innovation Model Evolution Process of Fanqing Furniture Company}

The confluence of challenges and opportunities stimulates Fanqing Company to choose value creation for strategic transformation, which includes two factors: driving and pulling. Its driving factors are mainly reflected from four aspects: Channel Internetization, Demand emotionalization, Hardware technology, Service concept. For pulling factors, it contains: Strategic obstacles, like insufficient talent reserve and outdated sales promotion; Personal motivation; Peer pressure. Fanqing Company followed the idea of development strategy construction: improve the innovation ecosystem $\rightarrow$ explore the value innovation model $\rightarrow$ propose a development strategy. Fanqing Company mainly expressed its thoughts in the $\mathrm{C} 2 \mathrm{~F} 2 \mathrm{C}$ value co-creation mode. Figure 1 shows the development strategy established by the company. 


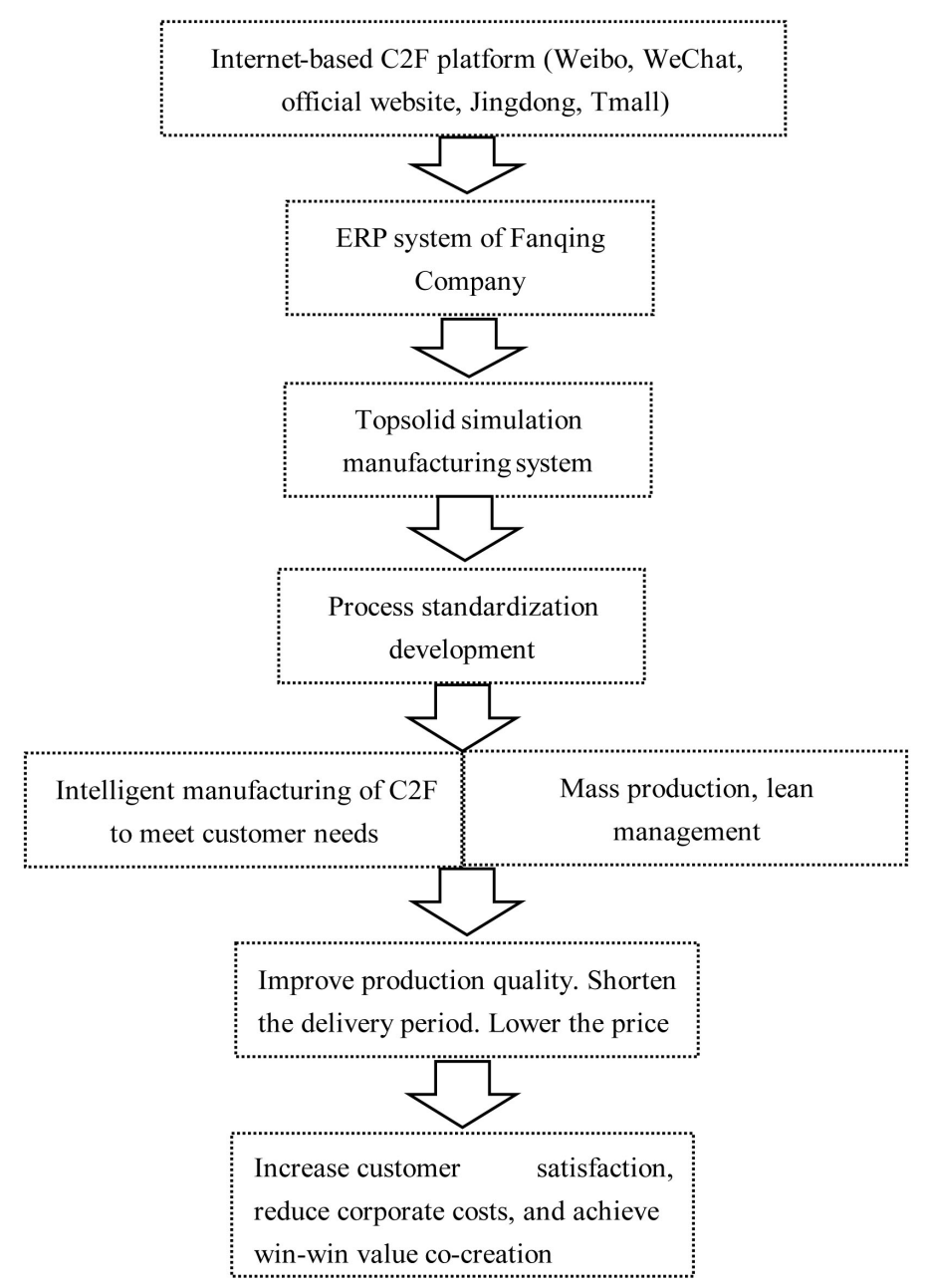

Figure 1. Framework of the development strategy of Fanqing Furniture Company.

First, starting from the C-end of $\mathrm{C} 2 \mathrm{~F}$, an Internet-based $\mathrm{C} 2 \mathrm{~F}$ platform was created, including Weibo, WeChat, official website and other marketing platforms, to provide personalized services and attract customers to the innovative ecosystem of Fanqing company. Moreover, the ERP system converts this personalized demand into production data, combining the TOPSOLID simulation manufacturing system and Fanqing existing intelligent manufacturing equipment to provide information to production. It accomplishes the standard technology development by manufacturing equipment and this standardized production can meet customer needs and a large-scale production. Ultimately, it achieves production quality boost, product delivery cycle cut, lower overall prices, improved customer satisfaction and significantly lower costs, yielding a win-win result.

The C2F2C value innovation model of Fanqing Hotel Furniture Company, is made of three components: $\mathrm{F} 2 \mathrm{C}, \mathrm{C} 2 \mathrm{~F}$ and $\mathrm{C} 2 \mathrm{~F} 2 \mathrm{C}$. In the process of $\mathrm{F} 2 \mathrm{C}$, Fanqing Company develops products based on the company's inherent model and standards for hotel customers to choose. It does not accept customization and factory production management is simple. The design tools are based on 
3DMAX or CAD drawing software. Fanqing applies F2C one-way sales and simultaneous production inventory. The business risk lies in product backlog, which is a hidden cause of the company's huge losses. It only has simple traditional management and low requirements for informatization. In this case, the company proposed a $\mathrm{C} 2 \mathrm{~F}$ model to make its furniture design individualized, so the company cooperated with Topsolid Company of French Dassault Group and introduced an ERP system, including a customer relationship management system, which solved the problem in the channel. But the cost was high, so the company proposed C2F2C. Within this strategy, Fanqing's first step is to clarify who the company is serving; to consider how to uniquely solve customer problems; how to establish and maintain customer relationships; and how to enable customers and companies to efficiently co-create value. Fanqing's C2F2C strategy is a fusion of $\mathrm{C} 2 \mathrm{~F}$ and $\mathrm{F} 2 \mathrm{C}$. It tailors products that meet the consumer individual needs, while reducing intermediate links to provide a forward-looking vision. As a manufacturer of hotel furniture products, Fanqing Company, an integrated company of front-end sales, production and design, and back-end services, needs to meet the individual customer needs and convert these large-scale needs into standardized production in the factory. This is the core idea of the C2F2C development strategy, showed in Figure 2.

\subsection{Fanqing Company's C2F2C Strategy Implementation}

Fanqing Company has gone through a series of stages during the implementation process. First of all, the hotel furniture company analyzes its own needs. In order to realize its needs successfully, Fanqing Furniture Company introduced ERP management information system to achieve information management from customers to factories to customers. Fanqing Company also cooperated with the Topsolid Group to incorporate Topsolid into the design core.

At the same time, according to the theoretical model of value co-creation, the company has made corresponding preparations and explorations. Firstly, under the network interactive extended value co-creation operation mode, Fanqing relies on the Internet to build a customer attraction platform, such as message push management, order schedule query, to manage and engage its own customers; at the same time, relying on the database to fully meet customer needs, the company needs to retain customers, so Fanqing introduced a Customer Relationship Management System (CRM). There are three stages: first, to analyze the customer's behavior before brand identification, to make different marketing plans; second, to manage customer information and product progress reminders; third, to regularly integrate and analyze after-sales problems, to extract the reasons for satisfaction and dissatisfaction.

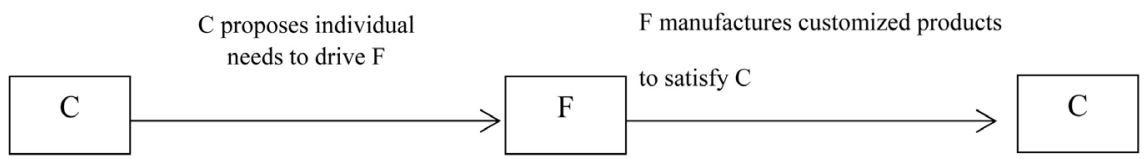

Figure 2. C2F2C model. 
Under the modular decomposition value co-creation model, $\mathrm{C} 2 \mathrm{~F} 2 \mathrm{C}$ is a very significant value co-creation model for Fanqing Company. According to the three principles of modularity mentioned above: it strengthens the management of stakeholders, clarifies the rights and responsibilities, and emphasizes the refinement function. Modular decomposition is mainly embodied in intelligent manufacturing. Fanqing Company is divided into 9 departments and 12 functional modules according to different functions. Each part performs its duties to achieve delicacy management. Under these subdivided, Fanqing also used TOPSOLID. It can even be said that TOPSOLID makes Fanqing to truly realize the value co-creation of modular decomposition. The application is mainly divided into four steps: Basic data preparation, modeling data preparation, specifications, and data preservation.

Resource integration sharing value co-creation model contains two main aspects: customers are engaged in the design and upstream and downstream supply chain. For customers participating in the design stage, Fanqing establishes three databases including the design solution database, the product database and the client information database. It can implement linkage and automatically allocate the optimal scheme, which is conducive to improving efficiency, promoting the whole consumption process and promoting additional consumption. In the upstream and downstream supply chains, Fanqing mainly aims at improving customer satisfaction for order management, service quality management and maintenance management.

\section{Conclusions}

C2F2C strategies meet clients' individualized demands, improve their satisfaction, achieve large-scale production \& manufacturing and lower corporate costs. In the meantime, the products provided for clients are featured with a short delivery period, a high quality and a low price. This achieves the value co-creation between Fanqing Company and the customer and generates a win-win effect.

First of all, this study summarized the contents related to the innovative ecological system of hotel furniture manufacturers and analyzed the external and internal innovative ecological environment of hotel furniture manufacturers and the value innovation mode. Secondly, the theory of value co-creation is being incorporated into the strategic transition system by an increasing number of fields and companies to seek bigger market share and higher profitability. Fanqing Company constructed and implemented the C2F2C development strategy based on value co-creation to solve the problems within a context of pervasive Internet access: high costs in the $\mathrm{C} 2 \mathrm{~F}$ mode and low client satisfaction in the F2C mode.

The theory of value co-creation is being incorporated into the strategic transition system by an increasing number of fields and companies to seek larger market share and profitability. Although many companies have accumulated a rich practical experience in value co-creation, few empirical studies undertook a professional analysis and discussion of the potential benefits and challenges of 
co-creation. This research on the experience of Fanqing Company provides referential values for the strategic transition and value co-creation solution of furniture companies, with obvious potential adaptations for other B2B businesses. It provided a discussion of the transition business process nodes within the furniture manufacturing industry and shed further light on the launch, implementation and results of value co-creation.

\section{Conflicts of Interest}

The authors declare no conflicts of interest regarding the publication of this paper.

\section{References}

[1] Tansley, A. (1947) The Early History of Modern Plant Ecology in Britain. Journal of Ecology, 35, 130-137. https://doi.org/10.2307/2256503

[2] Rostow, W.W. (1959) The Stages of Economic Growth. The Economic History Review (New Series), 12, 1-16. https://doi.org/10.1111/j.1468-0289.1959.tb01829.x

[3] Freeman, C. (1987) Technology Policy and Economic Performance: Lessons from Japan. Printer Publishers.

[4] Lundvall, B.A. (1992) National Innovation Systems: Towards a Theory of Innovation and Interactive Learning. Pinter, London.

[5] Simanis, E. and Hart, S. (2009) Innovation from the Inside out. $t$ Sloan Management Review, 50, 77-86.

[6] Adner, R. and Kapoor, R. (2010) Value Creation in Innovation Ecosystems: How the Structure of Technological Interdependence Affects Firm Performance in New Technology Generations. Strategic Management Journal, 31, 306-333. https://doi.org/10.1002/smj.821

[7] Li, W. (2014) Innovation 3.0 and Innovation Ecosystem. Science Research, 32, 1761-1770.

[8] Zhao, J., Liu, X.L., Sun, H.Y. and Ma, X.M. (2015) Science and Technology Management Based on Innovative Ecology. Science and Technology Management, 1, 18-27.

[9] Becker, G.S. (1965) A Theory of the Allocation of Time. The Economic Journal, 75, 493-517. https://doi.org/10.2307/2228949

[10] Ramaswamy, V. and Ozcan, K. (2018) What Is Co-Creation?: An Interactional Creation Framework and Its Implications for Value Creation. Journal of Business Research, 84, 196-205. https://doi.org/10.1016/j.jbusres.2017.11.027

[11] Zwass and Vladimir (2010) Co-Creation: Toward a Taxonomy and an Integrated Research Perspective. International Journal of Electronic Commerce, 15, 11-48. https://doi.org/10.2753/JEC1086-4415150101

[12] Etgar, M. (2008)A Descriptive Model of the Consumer Co-Production Process. Journal of the Academy of Marketing Science, 36, 97-108. https://doi.org/10.1007/s11747-007-0061-1

[13] Porter, M.E. (1985) Competitive Advantage: Creating and Sustaining Superior Performance.

[14] Bolton, R. and Saxena-Iyer, S. (2009) Interactive Services: A Framework, Synthesis and Research Directions. 23, 91-104. https://doi.org/10.1016/j.intmar.2008.11.002 
[15] Thomke, S. and von Hippel, E. (2002) Customers as Innovators: A New Way to Create Value. Harvard Business Review, 80, 74-81.

[16] Hippel, E.V. (2001) Perspective: User Toolkits for Innovation. Journal of Product Innovation Management, 18, 247-257. https://doi.org/10.1111/1540-5885.1840247

[17] Füller, Johann, Hutter, K. and Faullant, R. (2011) Why Co-Creation Experience Matters? Creative Experience and Its Impact on the Quantity and Quality of Creative Contributions. $R$ \& D Management, 41, 259-273. https://doi.org/10.1111/j.1467-9310.2011.00640.x

[18] Vargo, S.L. and Lusch, R.E. (2004) Evolving to a New Dominant Logic for Marketing. Journal of Marketing, 68, 1-17. https://doi.org/10.1509/jmkg.68.1.1.24036

[19] Paredes, M., Barrutia, R., Echebarria, J.M. and Carmen (2014) Resources for Value Co-Creation in E-Commerce: A Review. Electronic Commerce Research, 14, 111-136. https://doi.org/10.1007/s10660-014-9135-6

[20] Arnould, E.J. (2008) Service-Dominant Logic and Resource Theory. Journal of the Academy of Marketing Science, 36, 21-24.

https://doi.org/10.1007/s11747-007-0072-y

[21] Rosenbaum, M.S. and Massiah, C.A. (2007) When Customers Receive Support from Other Customers: Exploring the Influence of Intercustomer Social Support on Customer Voluntary Performance. Journal of Service Research, 9, 257-270. https://doi.org/10.1177/1094670506295851

[22] Spohrer, J. and Maglio, P.P. (2008) The Emergence of Service Science: Toward Systematic Service Innovations to Accelerate Co-Creation of Value. Production \& Operations Management, 17, 238-246. https://doi.org/10.3401/poms.1080.0027

[23] Agrawal, A.K. and Zillur, R. (2015) Roles and Resource Contributions of Customers in Value Co-Creation. International Strategic Management Review, 3, 144-160. https://doi.org/10.1016/j.ism.2015.03.001

[24] Langeard, E., Bateson, J., Lovelock, C.H. and Eiglier, P. (1981) Services Marketing: New Insights from Consumers and Managers. Marketing Science Institute, Cambridge, 81-104.

[25] Aarikka-Stenroos, L. and Jaakkola, E. (2012) Value Co-Creation in Knowledge Intensive Business Services: A Dyadic Perspective on the Joint Problem Solving Process. Industrial Marketing Management, 41, 15-26. https://doi.org/10.1016/j.indmarman.2011.11.008

[26] Zhang, T.C., Jahromi, M.F. and Kizildag, M. (2018) Value Co-Creation in a Sharing Economy: The End of Price Wars? International Journal of Hospitality Management, 71, 51-58. https://doi.org/10.1016/j.ijhm.2017.11.010

[27] Kuula, S., Harri, H. and Arto, T. (2018) Cost-Efficient Co-Creation of Knowledge Intensive Business Services. Service Business, 12, 779-808.

https://doi.org/10.1007/s11628-018-0380-y

[28] Lyons, P. and Brennan, L. (2019) Assessing Value from Business-to-Business Services Relationships: Temporality, Tangibility, Temperament, and Trade-Offs. Journal of Service Research, 22, 27-43. https://doi.org/10.1177/1094670518805569

[29] Melton, H. and Hartline, M.D. (2015) Customer and Employee Co-Creation of Radical Service Innovations. Journal of Services Marketing, 29, 112-123. https://doi.org/10.1108/JSM-02-2014-0048

[30] Vallaster, C., Von Wallpach and Sylvia (2018) Brand Strategy Co-Creation in a Nonprofit Context: A Strategy-as-Practice Approach. Nonprofit and Voluntary Sector Quarterly, 47, 984-1006. https://doi.org/10.1177/0899764018776373 